\title{
Numerical Results for the Solution of the Graetz Problem for a Bingham Plastic in Laminar Tube Flow with Constant Wall Temperature
}




\section{DISCLAIMER}

This report was prepared as an account of work sponsored by an agency of the United States Government. Neither the United States Government nor any agency Thereof, nor any of their employees, makes any warranty, express or implied, or assumes any legal liability or responsibility for the accuracy, completeness, or usefulness of any information, apparatus, product, or process disclosed, or represents that its use would not infringe privately owned rights. Reference herein to any specific commercial product, process, or service by trade name, trademark, manufacturer, or otherwise does not necessarily constitute or imply its endorsement, recommendation, or favoring by the United States Government or any agency thereof. The views and opinions of authors expressed herein do not necessarily state or reflect those of the United States Government or any agency thereof. 


\section{DISCLAIMER}

Portions of this document may be illegible in electronic image products. Images are produced from the best available original document. 


\section{Shor COVER ROFL}

Issued by Sandia National Laboratories, operated for the United States Department of Energy by Sandia Corporation.

NOTICE: This report was prepared as an account of work sponsored by an agency of the United States Government. Neither the United States Government nor any agency thereof, nor any of their employees, nor any of their contractors, subcontractors, or their employees, makes any warranty, express or implied, or assumes any legal liability or responsibility for the accuracy, completeness, or usefulness of any information, apparatus, prod. uct, or process disclosed, or represents that its use would not infringe privately owned rights. Reference herein to any specific commercial product, process, or service by trade name, trademark, manufacturer, or otherwise, does not necessarily constitute or imply its endorsement, recommendation or favoring by the United States Govermment, any agency theref or any of or favoring by the United States Government, any agency thereof or any of their contractors or subcontractors. The views and opinions expressed herein do not necessarily state or reflect those of the United States Government, any agency thereof or any of their contractors or subcontractors.

Printed in the United States of America Available from

National Technical Information Service

U.S. Department of Commerce

5285 Port Royal Road

Springfield, VA 22161

NTIS price codes

Printed copy: A02

Microfiche copy: A01 


\section{DISCLAIMER}

This report was prepared as an account of work sponsored by an agency of the United States Government. Neither the United States Government nor any agency thereof, nor any of their employees, makes any warranty, express or implied, or assumes any legal liability or responsibility for the accuracy, completeness, or usefulness of any information, apparatus, product, or process disclosed, or represents that its use would not infringe privately owned rights. Reference herein to any specific commercial product, process, or service by trade name, trademark, manufacturer, or otherwise does not necessarily constitute or imply its endorsement, recommendation, or favoring by the United States Government or any agency thereof. The views and opinions of authors expressed herein do not necessarily state or reflect those of the United States Government or any agency thereof.

\section{SAND8 4-0956}

Numerical Results for the Solution of the Graetz Problem for a Bingham Plastic in Laminar Tube Flow with Constant Wall Temperature

B. F. Blackwell

Sandia National Laboratories* Centrifuge, Climatic and Radiant Heat

Division 7531

\section{ABSTRACT}

The Graetz problem of developing temperature profile in a tube for a fully developed laminar velocity profile has been numerically solved for a Bingham plastic. Constant properties were assumed and viscous dissipation was ignored. Results are presented for local Nusselt number, average Nusselt number, and bulk fluid temperature each as a function of axial distance from the tube inlet. The laminar Newtonian fluid is a special case of the Bingham plastic; the results presented in this article for this case appear to be more accurate than those available in the literature.

\footnotetext{
*Sandia National Laboratories is a U.S. Department of Energy facility. This work was supported by the Department of Energy
} under contract DE-AC0476DP00789. 


\section{$\underline{\text { Page }}$}

ABSTRACT

i

NOMENCLATURE

iii-iv

INTRODUCTION

1

ANALYSIS

$2-6$

RESULTS

$6-7$

CONCLUSIONS

TABLE 1 Heat Transfer Results for Developing Flow of Bingham Plastic in a Tube with Constant Wall Temperature

REFERENCES

\section{LIST OF FIGURES}

Figure 1 Dimensionless Velocity Profile for Fully Leveloped Flow of a Bingham Plastic in Circular Tube $(c=\tau y / \tau w)$

Figure 2 Variation of Local Nusselt No $\left(\mathrm{Nu}_{\mathrm{x}}\right)$ with Dimensionless Axial Distance $\frac{\left(\mathrm{x} / \mathrm{x}_{\mathrm{O}}\right)}{\mathrm{Pe}}$ for $\mathrm{c}=0.0,0.2,0.4,0.6,0.8$, and $\frac{\mathrm{Pe}}{1.0}$.

Figure 3 Variation of Mean Nusselt No $\left(N u_{m}\right)$ with Dimensionless Axial Distance $\frac{\left(\mathrm{x} / \mathrm{r}_{\mathrm{O}}\right)}{\mathrm{Pe}}$ for $\mathrm{c}=0.0,0.2,0.4,0.6,0.8$, and $\stackrel{P e}{1.0}$.

Figure 4 Variation of Dimensionless Bulk Fluid Temperature $\left(\theta_{b}\right)$ with Dimensionless Axial Distance $\frac{\left(\mathrm{x} / \mathrm{r}_{\mathrm{O}}\right)}{\mathrm{Pe}}$ for $\mathrm{c}=0.0,0.2,0.4,0.6$, 0.8 , and 1.0 . 
NOMENCLATURE

C

$\tau_{y} / \tau_{w}$, ratio of yield stress to wall shear stress

$\mathrm{C}_{\mathrm{p}}$

specific heat at constant pressure

$\mathrm{C}_{\mathrm{n}} \quad$ constant in series solution

D pipe diameter

$\mathrm{G}_{\mathrm{n}} \quad$ constant, see Eq. (12)

$h_{\mathrm{x}} \quad$ local convective heat transfer coefficient, $h_{\mathrm{x}}=$ $q^{\prime \prime} /\left(t_{b}-t_{0}\right)$

$\mathrm{k}$ thermal conductivity

$\mathrm{Nu}_{\mathrm{X}} \quad=\mathrm{h}_{\mathrm{x}} \mathrm{D} / \mathrm{k}$, local Nusselt number

$\mathrm{Nu}_{\mathrm{m}} \quad$ average of $\mathrm{Nu}_{x}$ between entrance and axial location $\mathrm{x}$

$\dot{q}^{\prime \prime}(\mathrm{x}) \quad$ wall heat flux

Pe $\quad=\overline{\mathrm{u}} \mathrm{D} / \alpha$, Peclet number

r radial coordinate

$r_{0} \quad$ pipe radius

$r^{+} \quad=r / r_{0}$, dimensionless radius

$R_{n}\left(r^{+}\right) \quad$ eigenfunction

$t(x, r) \quad$ temperature

$t_{b} \quad$ bulk or mixing cup temperature

te uniform entrance temperature

to uniform wall temperature

$u(r) \quad$ axial velocity

$\mathrm{u}_{\max } \quad$ maximum axial velocity

$\bar{u} \quad$ average axial velocity

$\mathrm{u}^{+} \quad \mathrm{u} / \overline{\mathrm{u}}$

$x \quad$ axial coordinate

$x^{+}=\frac{x / r_{0}}{P e}$, dimensionless axial coordinate 


\section{GREEK}

$\alpha$

$\eta$

$\theta$

$\theta_{\mathrm{b}}$

$\lambda$

$\rho$

$\tau$

$\tau_{w}$

$\tau_{Y}$ $=\mathrm{k} / \rho \mathrm{C}_{\mathrm{p}}$, thermal diffusivity

Bingham viscosity

$=\frac{t_{0}-t(x, r)}{t_{0}-t_{e}}$, dimensionless temperature

$=\frac{t_{0}-t_{b}}{t_{0}-t_{e}}$ dimensionless bulk fluid temperature,
see Eq. (13)

eigenvalue

density

local shear stress

wall shear stress

yield shear stress 
Numerical Results for the Solution of the

Graetz Problem for a Bingham Plastic in

Laminar Tube Flow with Constant Wall Temperature

\section{INTRODUCTION}

Many fluids exhibit a yield stress, a stress which must be exceeded before the fluid will flow. Bird, et. al. [l] presented an extensive tabulation of materials with yield stresses; some common examples are drilling mud, sewage sludge, grease, paint, and thorium dioxide/methanol. If the local shear stress does not exceed the yield stress, these fluids will not support a velocity gradient. In pipe flow geometries, it is possible that the fluid region near the centerline (low shear stress, $\tau<\tau y$ ) may move as a solid (plug flow) while the fluid near the wall (high shear stress, $\tau>\tau_{y}$ ) supports a velocity gradient. Figure 1 presents representative laminar velocity profiles for Bingham plastics that exhibit a plug flow region.

This article was motivated by the desire to understand the heat transfer behavior of aqueous foams being used as a drilling fluid in high temperature petroleum and geothermal formations. In some applications, aqueous foams offer several advantages over conventional drilling fluids: 1) bottom hole pressure is reduced because aqueous foams have a much lower density than conventional drilling muds, 2) relatively little fall back of cuttings when circulation stops, and 3) low loss of circulation in porous formations. Additional details on the thermal behavior of aqueous foams circulating in geothermal wellbores are presented in Blackwell and ortega [2]. This report is an extension of the work of wissler and schechter [3] concerning the heat transfer behavior of Bingham plastics in developing tube flow. Slip at the wall has been ignored in this analysis. 


\section{ANALYSIS}

The constitutive equation for a Bingham plastic in pipe flow is of the form $[1,3,4]$

$$
\begin{aligned}
\frac{d u}{d r} & =0 \text { for }{ }^{0} \tau \leq \tau_{y} \\
-\frac{d u}{d r} & =\frac{1}{n}(\tau-\tau y) \text { for } \tau \geq \tau y
\end{aligned}
$$

where $u$ is the axial velocity component, $r$ is the radial coordinate, $\tau$ is the local shear stress, $\tau_{y}$ is the yield stress, and $\eta$ is the Bingham viscosity. For constant properties, the fully developed velocity profile has been shown to be $[1,3,4]$

$$
\begin{array}{ll}
\mathrm{u}=\frac{\tau_{\mathrm{w}} \mathrm{r}_{\mathrm{o}}}{2 \eta}\left[1-\left(\frac{r}{r_{\mathrm{O}}}\right)^{2}-2 \mathrm{c}\left(1-\frac{r}{r_{\mathrm{O}}}\right)\right] & \mathrm{c} \leq \frac{r}{\mathrm{r}_{\mathrm{O}}} \leq 1 \\
\mathrm{u}=\mathrm{u}_{\max ,} & 0 \leq \frac{r}{\mathrm{r}_{\mathrm{O}}} \leq \mathrm{c}
\end{array}
$$

where $\tau_{w}$ is the wall shear stress, $r_{O}$ is the pipe radius, and $c=\tau_{y} / \tau_{w}$. The maximum velocity $u_{\max }$ and the average velocity can be expressed as

$$
\begin{gathered}
u_{\max }=\frac{{ }^{\tau_{w} r_{O}}}{2 n}(1-c)^{2} \\
\bar{u}=\frac{{ }{ }_{w} r_{O}}{4 n}\left(1-\frac{4}{3} c+\frac{c^{4}}{3}\right)
\end{gathered}
$$

The dimensionless form of Eq. (4) is presented in Fig. 1. Note that $c=1$ corresponds to plug flow $\left(u=u_{\max }\right)$ while $c=0$ corresponds to laminar Newtonian flow.

If axial conduction is neglected ( $P e>100)$ and viscous dissipation ignored, the steady flow constant property form of the energy equation and its boundary conditions can be written as

$$
\begin{gathered}
\rho C_{p} u(r) \frac{\partial t}{\partial x}=k \frac{1}{r} \frac{\partial}{\partial r}\left(r \frac{\partial t}{\partial r}\right), t(o, r)=t_{e}, t\left(x, r_{0}\right)=t_{o}, \\
\frac{\partial t}{\partial r}(x, 0)=0
\end{gathered}
$$


This analysis is restricted to Prandt 1 number $>1$ but still sufficiently small that viscous dissipation is not important. The following dimensionless variables will be useful:

$$
\theta=\frac{t_{0}-t(x, r)}{t_{O}-t_{e}}, r^{+}=\frac{r}{r_{O}}, u^{+}=\frac{u}{\bar{u}}, x^{+}=\frac{x / r_{O}}{P e}, P e=\frac{\bar{u} D}{\alpha}
$$

where $t_{0}$ is the wall temperature, $t_{e}$, is the uniform inlet fluid temperature, $\alpha$ is the thermal diffusivity, and $P e$ is the dimensionless Peclet number. For uniform wall temperature $t_{0}$ and inlet temperature $t_{e}$, the dimensionless energy equation is $\frac{u^{+}}{2} \frac{\partial \theta}{\partial x^{+}}=\frac{1}{r^{+}} \frac{\partial}{\partial r^{+}}\left(r^{+} \frac{\partial \theta}{\partial r^{+}}\right), \theta\left(0, r^{+}\right)=1, \theta\left(x^{+}, 1\right)=0, \frac{\partial \theta\left(x^{+}, 0\right)}{\partial r^{+}}=0$

with the dimensionless velocity profile being given by

$$
\begin{array}{rlrl}
u^{+} & =\frac{2\left[1-r^{+2}-2 c\left(1-r^{+}\right)\right]}{1-\frac{4}{3} c+\frac{c^{4}}{3}} & c \leq r^{+} \leq 1 \\
& =\frac{2(1-c)^{2}}{I-\frac{4}{3} c+\frac{c}{3}^{4}} & & 0 \leq r^{+} \leq c
\end{array}
$$

The classical separation of variables solution to Eq. (7) leads to

$$
\theta\left(x^{+}, r^{+}\right)=\sum_{n=0}^{\infty} C_{n} R_{n}\left(r^{+}\right) \exp \left(-\lambda_{n}^{2} x^{+}\right)
$$

where $C_{n}$ is a constant to be determined from the boundary conditions and $R_{n}\left(r^{+}\right)$and $\lambda_{n}$ are eigenfunctions and eigenvalues respectively that are determined from the solution of

$$
\frac{d}{d r^{+}}\left(r^{+} \frac{d R_{n}}{d r^{+}}\right)+\lambda_{n}^{2} \frac{u^{+}}{2} r^{+} R_{n}=0 \quad R_{n}(1)=0, \frac{d R_{n}(0)}{d r^{+}}=0
$$

From the orthogonality condition, 


$$
C_{n}=\frac{\int_{0}^{1} \frac{u^{+}}{2} r^{+} R_{n} d r^{+}}{\int_{0}^{1} \frac{u^{+}}{2} r^{+} R_{n}^{2} d r^{+}}=\frac{\frac{-2}{\lambda_{n}^{2}} \frac{d R_{n}(1)}{d r^{+}}}{\int_{0}^{1} u^{+} r^{+} R_{n}^{2} d r^{+}}
$$

A more convenient constant $G_{n}$ will be defined as

$$
G_{n}=-\frac{C_{n}}{2} \frac{d R_{n}(1)}{d r^{+}}=\frac{\left[\mathrm{dR}_{n}(1) / d r^{+}\right]^{2} / 2}{\lambda_{n}^{2} \int_{0}^{1} \frac{u^{+}}{2} r^{+} R_{n}^{2} \mathrm{dr}^{+}}
$$

From Eq. (9), several useful heat transfer parameters can be developed. The dimensionless bulk fluid temperature is

$$
\theta_{b}\left(x^{+}\right)=\frac{t_{0}-t_{b}}{t_{0}-t_{e}}=2 \int_{0}^{1} u^{+} \theta r^{+} d^{+}=8 \sum_{n=0}^{\infty} \frac{G_{n}}{\lambda_{n}^{2}} \exp \left(-\lambda_{n}^{2} x^{+}\right)
$$

where $t_{b}$ is the bulk fluid or mixing cup temperature. Defining the local heat transfer coefficient in terms of the local temperature difference $\left(t_{b}-t_{0}\right)$, the local Nusselt number becomes

$$
N u_{x}=\frac{h_{x} D}{k}=\frac{-2}{\theta_{b}} \frac{\partial \theta(x, 1)}{\partial r^{+}}=\frac{4}{\theta_{b}} \sum_{n=0}^{\infty} G_{n} \exp \left(-\lambda_{n}^{2} x^{+}\right)
$$

The average Nu between the entrance and any arbitrary $\mathrm{x}^{+}$is given quite simply by

$$
N u_{m}\left(x^{+}\right)=\frac{1}{x^{+}} \int_{0}^{x^{+}} N u_{x} d x^{+}=\frac{1}{2 x^{+}} \ln \left(1 / \theta_{b}\right)
$$

Eq.(10) is the classical Sturm-Liouville problem. A closed form analytical solution exists for plug flow ( $c=1$, see Burmeister [5] for a discussion), Sellars, Tribus, and klein [6] developed an approximate solution for laminar Newtonian 
flow $(c=0)$, and Wissler and schechter [3] numerically determined the first seven eigenvalues and eigenfunctions for $\mathrm{c}=0.0,0.25,0.5,0.75$, and 1.0 . Additional works are referenced in [1]. The number of eigenvalues and eigenfunctions reported by wissler and schechter [3] were found to be inadequate for small values of $\mathrm{x}^{+}$and the calculations were extended to include the first 60 eigenvalues for $c=0.0$, $0.2,0.4,0.6,0.8,1.0$.

The general sturm-Liouville problem can be written as

$$
\frac{d}{d x}\left(p(x) \frac{d}{d x} \psi(x)\right)+(q(x)+\lambda r(x)) \psi(x)=0 \quad a \leq x \leq b
$$

with boundary conditions of the form

$$
\begin{aligned}
& A_{1} \psi(a)+A_{2} P(a) \frac{d}{d x} \psi(a)=0 \\
& B_{1} \psi(b)+B_{2} p(b) \frac{d}{d x} \psi(b)=0
\end{aligned}
$$

where $p(x), q(x)$, and $r(x)$ are arbitrary functions and $\psi(x)$ is the eigenfunction. The numerical results presented in this article were produced by the SLEIGN code, described by Bailey [7]. This code internally transforms the independent variable $x$ onto the interval $(-1,1)$. Next, the second order differential equation given by Eq. (16) is replaced (within the code) by an equivalent system of two first order equations for the new dependent variables $\rho(x)$ and $\phi(x)$ defined by

$$
\begin{aligned}
\psi(x) & =\rho(x) \sin \phi(x) \\
p(x) \psi^{\prime}(x) & =z \rho(x) \cos \phi(x)
\end{aligned}
$$

where $z$ is a scaling factor determined by the code. If $z=1$, this is known as the prufer transformation [7]. The eigenvalue $\lambda$ is then determined by numerically integrating the transformed version of Eq. (16) from both boundaries toward the interior of the internal $(a, b)$ with an assumed $\lambda$. The integration is terminated at an interior point $x=M$ and the solution from the left 
$\psi_{L}(M ; \lambda)$ is compared with the solution from the right $\psi_{R}(M$; $\lambda)$. During both the "left" and "right" integration process, the correct boundary conditions are always used. The code automatically chooses the match point $x=M$, picks an initial guess for $\lambda$ and adjusts $\lambda$ until $\psi_{L}=\psi_{R}$ within a user specified tolerance. The code has been extensively tested and additional details can be found in Bailey [7].

RESULTS

Table 1 presents numerical results for the local Nusselt number $\left(\mathrm{Nu}_{\mathrm{x}}\right)$, average Nusselt number $\mathrm{Nu}$, and bulk fluid temperature as a function of the dimensionless entry length $\mathbf{x}^{+}$. All calculations were performed on a CDC Cyber $170 /$ Model 855 computer using single precision arithmetic (nominally 14 $1 / 2$ digits). The series for $N u_{x}$ converges more slowly than that for ${ }^{\theta} b$. A relative convergence criteria of $10^{-6}$ on the last term (normalized by the partial sum) was used. sixty eigenvalues were adequate for convergence for all values of $\mathrm{x}^{+}$except 0.0001 ; for this $\mathrm{x}^{+}$, the relative error was typically less than $7 \times 10^{-5}$ for all values of $c$. The numerical results for $c=1.0$ were compared with the analytical solution; for this case, the eigenvalues are the roots of $J_{0}\left(\lambda_{n} / \sqrt{2}\right)=$ 0 and the eigenfunctions are $R_{n}\left(r^{+}\right)=J_{0}\left(\lambda_{n} / \sqrt{2} r^{+}\right)$. The results from SLEIGN were identical to the analytical solution for the number of significant digits printed, except for $\mathrm{x}^{+}=0.0001$. For example, the analytical result was $\mathrm{Nu}_{\mathrm{x}}=$ 81.352 while the numerical result was 81.365 . The $c=1$ (plug flow) results were also compared with those presented in Burmeister [5]; exact agreement was obtained for large $\mathrm{x}^{+}$but it appears that the results of [4] are not accurate at small $\mathrm{x}^{+}$. Sellars, Tribus, and Klein [6] developed an approximate solution for $c=0$ (laminar Newtonian flow) and their results for $\mathrm{Nu}_{\mathrm{X}}, \mathrm{Nu}_{\mathrm{m}}$, and $\theta_{\mathrm{b}}$ are tabulated in Kays and Crawford [8] and Burmeister [9]. Again, these results do not appear to be accurate at small $\mathbf{x}^{+}$.

The results of Table $I$ are also presented graphically in Figures 2-4. For $c$ near zero, Nu and the bulk fluid 
temperature are not very sensitive to $c$; for $c$ near unity, the computed results are much more sensitive to $c$. These results stem from the dependence of the velocity profile on $c$ (see Fig. 1).

CONCLUSIONS

The numerical solution of the Graetz problem of the development of the thermal boundary layer within a tube for laminar fully developed velocity profile under a constant wall temperature boundary condition was presented for a Bingham plastic. Local Nusselt number, average Nusselt number and bulk fluid temperature were presented as a function of dimensionless distance from the inlet. The results for plug flow agree with the analytical solution, and the laminar Newtonian flow $(c=0)$ results of this work appear to be more accurate than those available in the literature. 
Table 1 Heat Transfer Results for Developing Flow of Bingham Plastic in a Tube with Constant Wall Temperature

\begin{tabular}{|c|c|c|c|}
\hline $\mathrm{x}^{+}$ & $\mathrm{Nu}_{\mathrm{X}}$ & $N u_{m}$ & $\theta_{b}$ \\
\hline $\begin{array}{r}.0001 \\
.0002 \\
.0004 \\
.0010 \\
.0020 \\
.0040 \\
.0100 \\
.0200 \\
.0400 \\
.1000 \\
.2000 \\
.4000 \\
1.0000 \\
2.0000 \\
4.0000 \\
10.0000\end{array}$ & $\begin{array}{l}81.352 \\
58.008 \\
41.502 \\
26.876 \\
19.531 \\
14.372 \\
9.844 \\
7.744 \\
6.437 \\
5.817 \\
5.783 \\
5.783 \\
5.783 \\
5.783 \\
5.783 \\
5.783\end{array}$ & $\begin{array}{r}161.1 .46 \\
114.413 \\
81.375 \\
52.074 \\
37.322 \\
26.914 \\
17.731 \\
13.174 \\
10.063 \\
7.620 \\
6.705 \\
6.244 \\
5.968 \\
5.875 \\
5.829 \\
5.802\end{array}$ & $\begin{array}{l}.9682847 \\
.9552662 \\
.9369734 \\
.9010919 \\
.8613197 \\
.8062926 \\
.7014360 \\
.5904024 \\
.4470782 \\
.2178524 \\
.0684313 \\
.0067703 \\
.0000066 \\
.0000000 \\
.0000000 \\
.0000000\end{array}$ \\
\hline \multicolumn{4}{|c|}{$c=0.8$} \\
\hline $\begin{array}{r}.0001 \\
.0002 \\
.0004 \\
.0010 \\
.0020 \\
.0040 \\
.0100 \\
.0200 \\
.0400 \\
.1000 \\
.2000 \\
.4000 \\
1.0000 \\
2.0000 \\
4.0000 \\
10.0000\end{array}$ & $\begin{array}{l}39.913 \\
31.453 \\
24.774 \\
18.079 \\
14.271 \\
11.299 \\
8.366 \\
6.777 \\
5.703 \\
5.111 \\
5.066 \\
5.066 \\
5.066 \\
5.066 \\
5.066 \\
5.066\end{array}$ & $\begin{array}{l}60.569 \\
47.802 \\
37.701 \\
27.529 \\
21.704 \\
17.129 \\
12.569 \\
10.003 \\
8.069 \\
6.401 \\
5.739 \\
5.402 \\
5.200 \\
5.133 \\
5.099 \\
5.079\end{array}$ & $\begin{array}{l}.9879594 \\
.9810610 \\
.9702898 \\
.9464307 \\
.9168451 \\
.8719433 \\
.7777295 \\
.6702263 \\
.5243750 \\
.2779934 \\
.1007254 \\
.0132775 \\
.0000304 \\
.0000000 \\
.0000000 \\
.0000000\end{array}$ \\
\hline \multicolumn{4}{|c|}{$c=0.6$} \\
\hline $\begin{array}{l}.0001 \\
.0002 \\
.0004 \\
.0010 \\
.0020 \\
.0040 \\
.0100 \\
.0200\end{array}$ & $\begin{array}{r}33.304 \\
26.265 \\
20.706 \\
15.135 \\
11.972 \\
9.520 \\
7.149 \\
5.892\end{array}$ & $\begin{array}{r}50.486 \\
39.866 \\
31.462 \\
22.998 \\
18.153 \\
14.353 \\
10.591 \\
8.503\end{array}$ & $\begin{array}{r}.9899536 \\
.9841801 \\
.9751443 \\
.9550453 \\
.9299621 \\
.8915229 \\
.8091051 \\
.7116963\end{array}$ \\
\hline
\end{tabular}


Table 1 Heat Transfer Results for Developing Flow of Bingham Plastic in a Tube with Constant Wall Temperature (Cont)

\begin{tabular}{|c|c|c|c|}
\hline \multicolumn{4}{|c|}{$c=0.6$} \\
\hline$x^{+}$ & $\mathrm{Nu}{ }_{\mathrm{X}}$ & $\mathrm{Nu}_{\mathrm{m}}$ & ${ }^{\theta} b$ \\
\hline $\begin{array}{r}.0400 \\
.1000 \\
.2000 \\
.4000 \\
1.0000 \\
2.0000 \\
4.0000 \\
10.0000\end{array}$ & $\begin{array}{l}5.038 \\
4.539 \\
4.494 \\
4.493 \\
4.493 \\
4.493 \\
4.493 \\
4.493\end{array}$ & $\begin{array}{l}6.943 \\
5.593 \\
5.048 \\
4.771 \\
4.604 \\
4.549 \\
4.521 \\
4.504\end{array}$ & $\begin{array}{r}.5738254 \\
.3267612 \\
.1327436 \\
.0220013 \\
.0001002 \\
.0000000 \\
.0000000 \\
.0000000\end{array}$ \\
\hline & & & \\
\hline $\begin{array}{r}.0001 \\
.0002 \\
.0004 \\
.0010 \\
.0020 \\
.0040 \\
.0100 \\
.0200 \\
.0400 \\
.1000 \\
.2000 \\
.4000 \\
1.0000 \\
2.0000 \\
4.0000 \\
10.0000\end{array}$ & $\begin{array}{r}30.513 \\
24.065 \\
18.970 \\
13.860 \\
10.956 \\
8.703 \\
6.520 \\
5.364 \\
4.585 \\
4.126 \\
4.082 \\
4.081 \\
4.081 \\
4.081 \\
4.081 \\
4.081\end{array}$ & $\begin{array}{l}46.252 \\
36.524 \\
28.825 \\
21.068 \\
16.625 \\
13.139 \\
9.684 \\
7.764 \\
6.332 \\
5.094 \\
4.593 \\
4.337 \\
4.183 \\
4.132 \\
4.105 \\
4.091\end{array}$ & $\begin{array}{l}.9907923 \\
.9854966 \\
.9772039 \\
.9587394 \\
.9356627 \\
.9002269 \\
.8239285 \\
.7330460 \\
.6025852 \\
.3610479 \\
.1592788 \\
.0311343 \\
.0002326 \\
.0000001 \\
.0000000 \\
.0000000\end{array}$ \\
\hline & & & \\
\hline $\begin{array}{r}.0001 \\
.0002 \\
.0004 \\
.0010 \\
.0020 \\
.0040 \\
.0100 \\
.0200 \\
.0400 \\
.1000 \\
.2000 \\
.4000 \\
1.0000 \\
2.0000 \\
4.0000 \\
10.0000\end{array}$ & $\begin{array}{r}29.061 \\
22.921 \\
18.066 \\
13.196 \\
10.426 \\
8.274 \\
6.186 \\
5.075 \\
4.319 \\
3.861 \\
3.814 \\
3.813 \\
3.813 \\
3.813 \\
3.813 \\
3.813\end{array}$ & $\begin{array}{l}44.053 \\
34.788 \\
27.454 \\
20.064 \\
15.830 \\
12.505 \\
9.208 \\
7.372 \\
5.999 \\
4.803 \\
4.314 \\
4.063 \\
3.913 \\
3.863 \\
3.838 \\
3.823\end{array}$ & $\begin{array}{l}.9912281 \\
.9861812 \\
.9782760 \\
.9606662 \\
.9386436 \\
.9047981 \\
.8318034 \\
.7446142 \\
.6188482 \\
.3826712 \\
.1780752 \\
.0387508 \\
.0003994 \\
.0000002 \\
.0000000 \\
.0000000\end{array}$ \\
\hline
\end{tabular}


Table 1 Heat Transfer Results for Developing Flow of Bingham Plastic in a Tube with Constant Wall Temperature (Cont)

$$
c=0.0 \text { (Laminar Newtonian) }
$$

$x^{+}$
.0001
.0002
.0004
.0010
.0020
.0040
.0100
.0200
.0400
.1000
.2000
.4000
1.0000
2.0000
4.0000
10.0000

\begin{tabular}{c}
${ }_{x}^{N u}$ \\
\hline 28.244 \\
22.278 \\
17.559 \\
12.824 \\
10.130 \\
8.036 \\
6.002 \\
4.916 \\
4.172 \\
3.710 \\
3.658 \\
3.657 \\
3.657 \\
3.657 \\
3.657 \\
3.657
\end{tabular}

\begin{tabular}{c}
$\mathrm{Nu}_{\mathrm{m}}$ \\
\hline 42.814 \\
33.810 \\
26.583 \\
19.501 \\
15.384 \\
12.152 \\
8.943 \\
7.155 \\
5.815 \\
4.541 \\
4.156 \\
3.906 \\
3.757 \\
3.707 \\
3.682 \\
3.667
\end{tabular}

$\theta_{\mathrm{b}}$

.9914737 .9865668

.9788795

.9617496

.9403183

.9073635

.8362189

.7511056

.6280276

.3952988

.1897101

.0439350

.0005458

.0000004

.0000000

.0000000 
1. R.B. Bird, G.C. Dai, and B.J. Yarusso, The Rheology and Flow of Viscoplastic Materials, Reviews in Chemical Engineering, Vol. 1, No. 1, 1982, pp 1-70.

2. B.F. Blackwell and A. Ortega, A Quasi-Steady Model for Predicting Temperature of Aqueous Foams Circulating in Geothermal Wellbores, Proceedings ASME/JSME Thermal Engineering Joint Conference, Vol II, pp 101-111, 1983.

3. E.H. Wissler and R.S. Schechter, The Graetz-Nusselt Problem (with Extension) for a Bingham Plastic, Chemical Engineering Progress Symposium Series No. 29, Vol 55, pp 203-208 (1959).

4. R.B. Bird, W.E. Stewart, and E.N. Lightfoot, Transport Phenomena, Wiley, New York, 1960.

5. L.C. Burmeister, Convective Heat Transfer, John Wiley, New York, 1983.

6. J.R. Sellars, M. Tribus, and J.S. Klein, Heat Transfer to Laminar Flow in a Round Tube or Flat Conduit-The Graetz Problem Extended, Transactions ASME, Vol 78, pp 441-448, Feb. 1956.

7. P.B. Bailey, SLEIGN An Eigenvalue-Eigenfunction Code for Sturm-Liouville Problems, Sandia National Laboratories, SAND77-2044, March 1978.

8. W.M. Kays and M.E. Crawford, Convective Heat and Mass Transfer, 2nd Ed., McGraw-Hill, New York, 1980. 


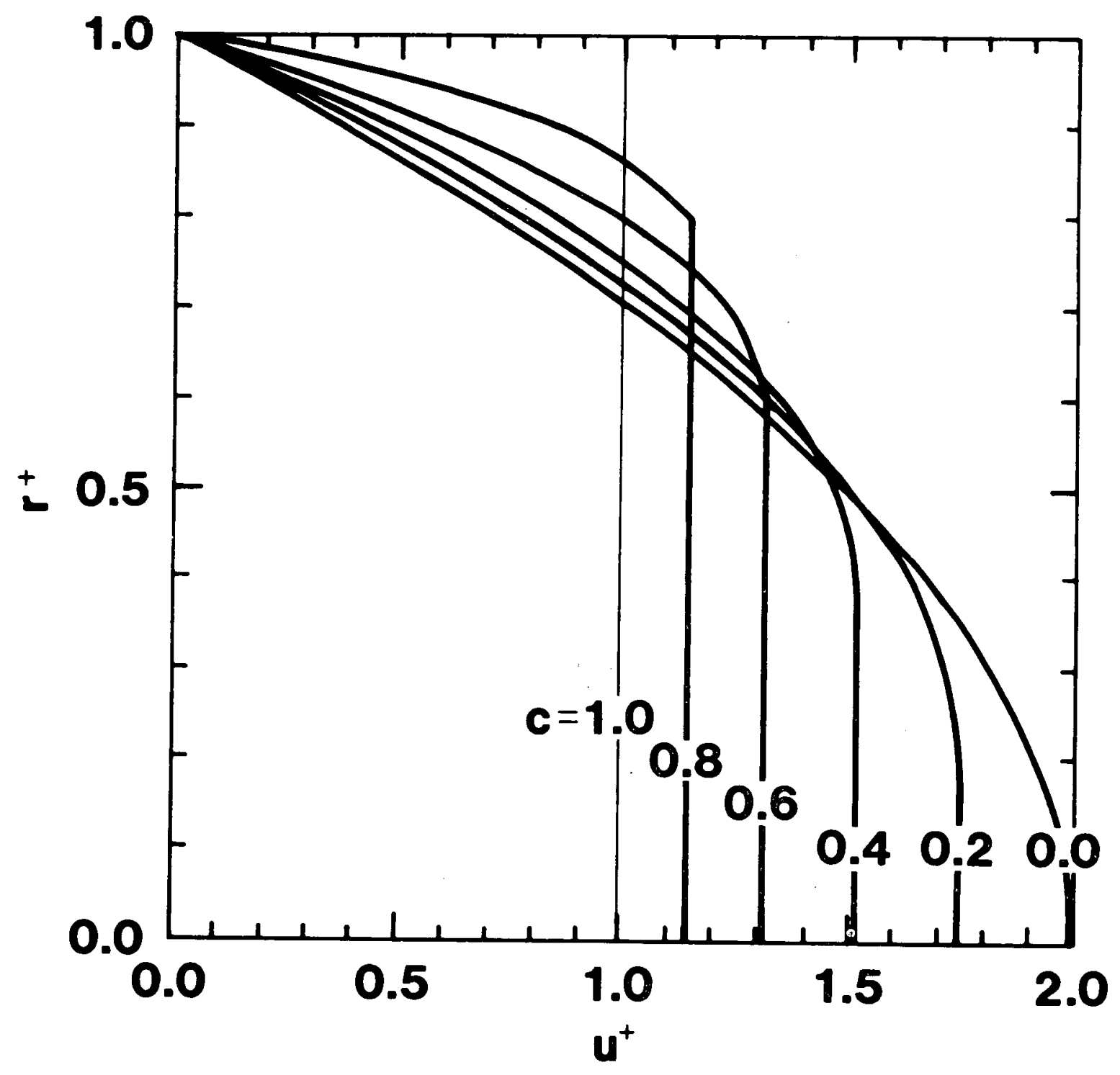

Figure 1 Dimensionless Velocity Profile for Fully Developed Flow of a Bingham Plastic in Circular Tube $(c=\tau y / \tau w)$ 


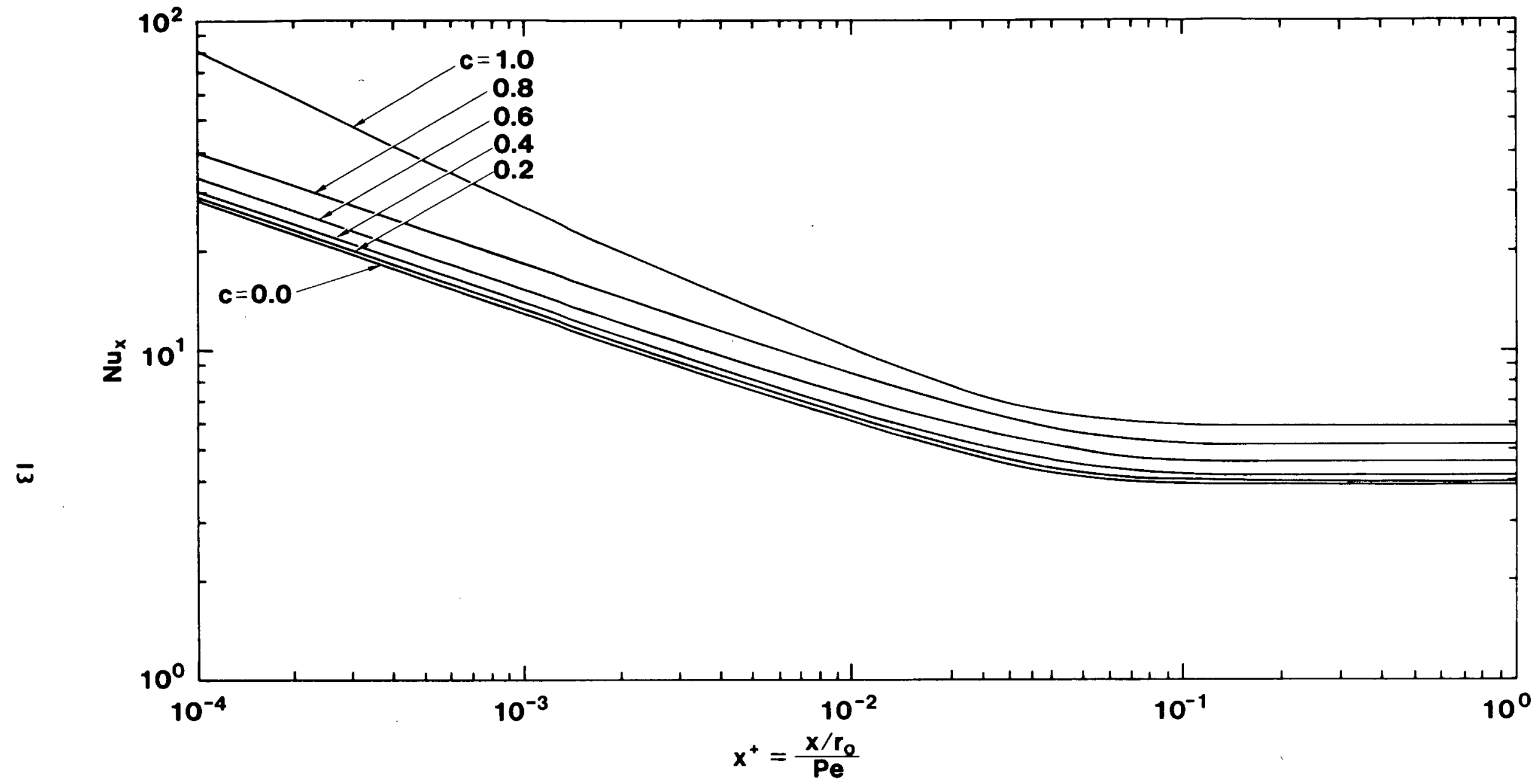

Figure 2 Variation of Local Nusselt No $\left(N u_{x}\right)$ with Dimensionless Axial Distance $\frac{\left(\mathrm{x} / \mathrm{r}_{\mathrm{O}}\right)}{\mathrm{Pe}}$ for $\mathrm{c}=0.0,0.2,0.4,0.6,0.8$, and 1.0 . 


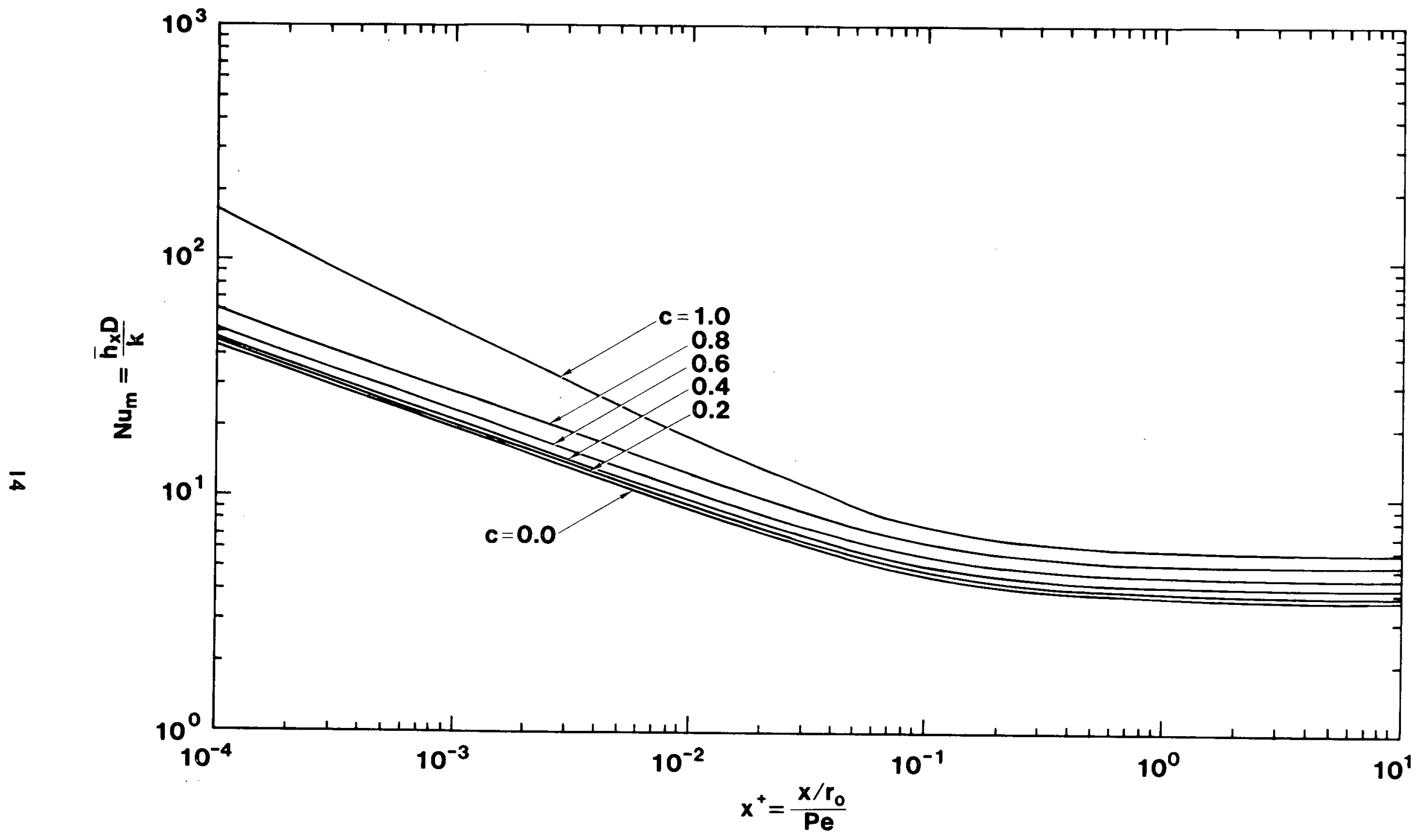

Figure 3 Variation of Mean Nusselt No $\left(\mathrm{Nu}_{\mathrm{m}}\right)$ with Dimensionless Axial Distance $\frac{\left(\mathrm{x} / \mathrm{r}_{\mathrm{O}}\right)}{\mathrm{Pe}}$ for $\mathrm{c}=0.0,0.2,0.4,0.6,0.8$, and 1.0 . 


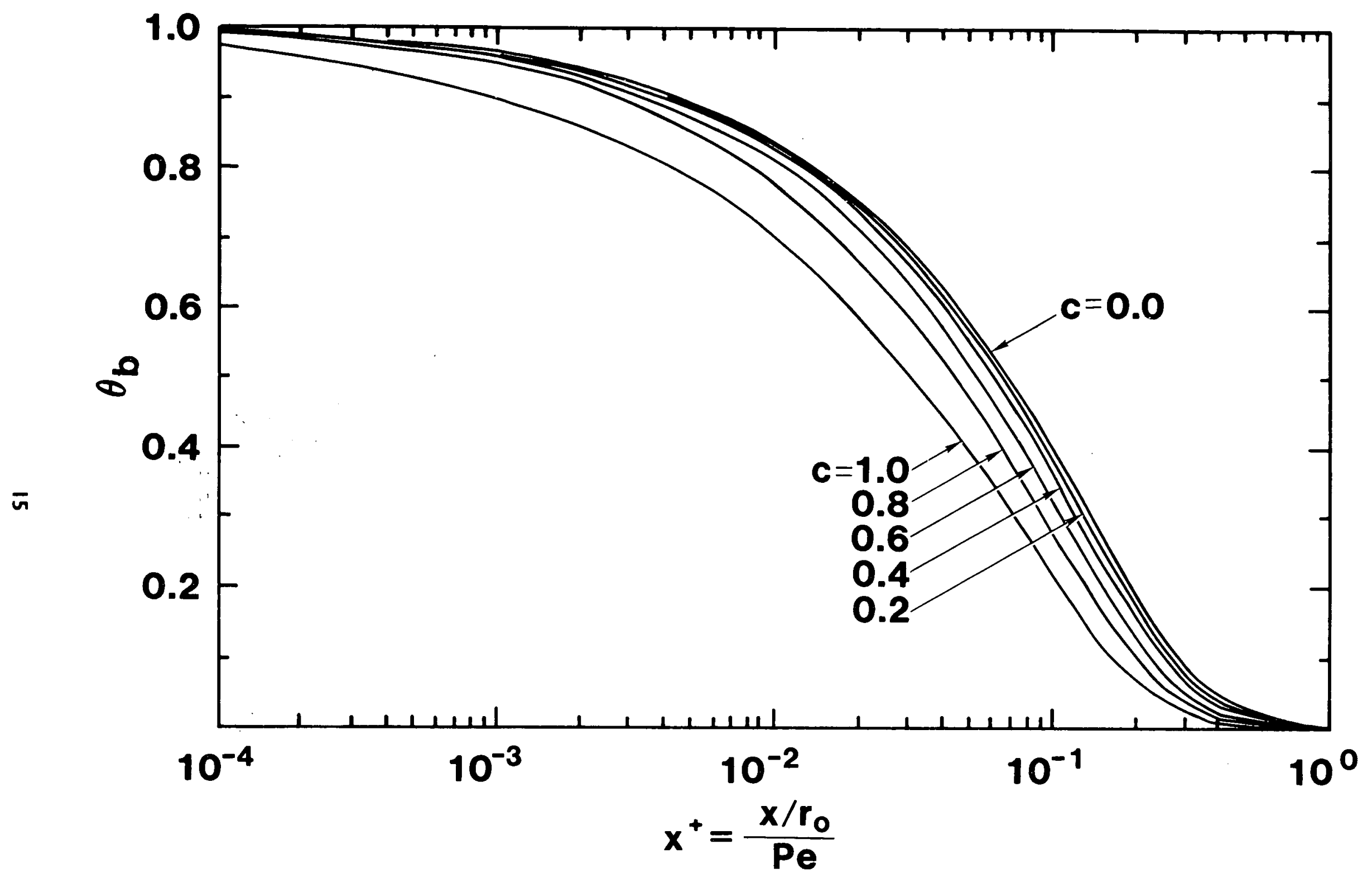

Figure 4 Variation of Dimensionless Bulk Fluid Temperature $\left(\theta_{b}\right)$ with Dimensionless Axial Distance $\frac{\left(\mathrm{x} / \mathrm{r}_{\mathrm{O}}\right)}{\mathrm{Pe}}$ for $\mathrm{c}=0.0,0.2,0.4,0.6,0.8$, and 1.0 . 
Distribution:

TID-4500-R-66-UC-66C (507)

Advanced Drilling Corp. 2060 Plymouth st.

Mountain View, CA 94043

Attn: W. Littmann

Tom Anderson

17726 S.W.

Overlook Inn,

Lake Oswego, OR 97034

Ed Bingman

Shell Oil Company

Two Shell plaza

P.O. Box 2099

Houston, TX 77001

Christensen, Inc.

Diamond Technology Center

2532 South 3270 West

Salt Lake City, UT 84119

Attn: Jim Carroll

Larry Diamond

Dyna-Drill

P.O. Box C-19576

Irvine, CA 92713

John E. Fontenot

NL Petroleum Services

P.O. Box 60087

Houston, TX 77205

Dr. Melvin Friedman

Professor of Geology

Center for Tectonophysics and Dept. of Geology

Texas A\&M University

College Station, TX 77843

Galveston-Houston Company

5229 Winfield

P.O. Box 2207

Houston, TX 77001

Attn: J.K. Heilhecker

James $W$. Lanford

Security Division

Dresser Industries, Inc.

P.O. Box 24647

Dallas, TX 75224
B. J. Livesay

2616 Angell Ave.

San Diego, CA 92122

Harvey E. Mallory

P.O. Box 54696

Tulsa, OK 74155

Ed Martin

Superior Oil

Eastern Division

P.O. Box 51108 OCS

Lafayette, LA 70505

Meridian Corporation

5113 Leesburg Pike

Suite 700

Falls Church, VA 22041

Attn: Deepak Kenkeremath

Maurer Engineering Inc.

2916 West T.C. Jester

Houston, TX 77018

Attn: W. C. Maurer

Gene Polk

NL Baroid

6400 Uptown Blvd. N.E. 365 W

Albuquerque, NM 87110

Del E. Pyle

Union Geothermal Division

Union Oil Co. of California

Union Oil Center

Los Angeles, CA 90017

John C. Rowley

Los Alamos National Labs.

Mail Stop 570

Los Alamos, NM 87545

Prof. Barry Raleigh

Lamont Doherty Geological

observatory of Columbia

University

Palisades, NY 10964 
William D. Rumbaugh

Research and Development

Otis

P.O. Box 34380

Dallas, $\mathrm{TX} 75234$

Ed Schmidt

400 East 57 th $\mathrm{St}$.

New York, NY 10022

Dwight Smith

Halliburton

Drawer 1431

Duncan, OK 73533

N.L. Sperry Sun

P.O. Box 69

Sugar Land, TX 77479

Attn: Dr. S. G. Varnado

Tom Warren

Phillips Petroleum Company

Geothermal Operations

655 East 4500 South

Salt Lake City, UT 84107

U.S. Department of Energy (8)

Office of Energy Research

Washington, DC 20545

Attn: George Y. Jordy ER 31

Robert E. Rader ER 32

U.S. Department of Energy

Geothermal Hydropower

Technologies Division

Forrestal Bldg., C.E. 324

1000 Independence Ave. S.W.

Washington, DC 20585

Attn: J. Bresee

R. Toms

D. Allen

U.S. Department of Energy

Office of Basic Energy Sciences

Mail stop J309

Washington, DC 20585

Attn: George Kolstad

W. K. Technology

9777 Harwin Dr.

Suite 408

Houston, TX 77036

Attn: Frank O'Brien
W. P. Grace, DOE/ALO

Nuclear \& Geosciences

Division

$\begin{array}{ll}1512 & \text { J. C. Cummings } \\ & \text { attn: L. A. Mondy } \\ 1513 & \text { D. W. Larson } \\ & \text { attn: S. K. Griffiths } \\ 1813 & \text { A. M. Kraynik } \\ 1813 & \text { P. B. Rand } \\ 1824 & \text { W. D. Drotning } \\ 3141 & \text { L. J. Erickson (5) } \\ 3151 & \text { W. L. Garner (3) } \\ 6000 & \text { E. H. Beckner } \\ 6200 & \text { V. L. Dugan } \\ 6240 & \text { R. K. Traeger } \\ 6241 & \text { J. R. Kelsey } \\ 6241 & \text { L. E. Duda (20) } \\ 6246 & \text { B. Granoff } \\ 6247 & \text { P. J. Hommert } \\ 6250 & \text { B. W. Marshall } \\ 6252 & \text { H. M. Dodd } \\ 6256 & \text { D. Engi } \\ 7530 & \text { T. B. Lane } \\ 7531 & \text { B. F. Blackwell (10) } \\ 7537 & \text { N. R. Keltner } \\ 8214 & \text { M. A. Pound }\end{array}$

